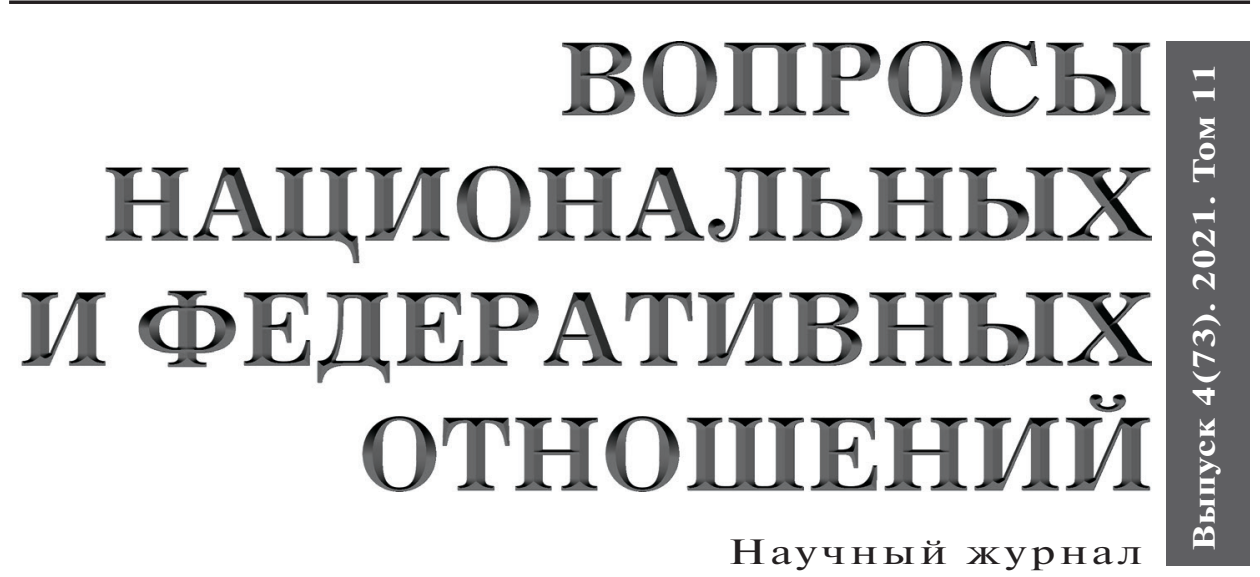

Журнал «Вопросы национальных и федеративных отношений» включен в перечень рецензируемых научных изданий ВАК, в которых должны быть опубликованы основные научные результаты на соискание ученой степени кандидата наук, на соискание ученой степени доктора наук по политическим и историческим наукам 


\section{Научный журнал}

Вячеслав Александрович МИХАЙЛОВ

Рамазан Гаджимурадович АБДУЛАТИПОВ

\section{Любовь Федоровна БОЛТЕНКОВА \\ Владимир Иванович ВАСИЛЕНКО}

Владимир Александрович ВОЛОх

Вадим Витальевич

ГАЙДУК

Леокадия Михайловна ДРОБИЖЕВА

\section{Владимир Юрьевич} ЗОРИН

Раушан Мусахановна КАНАПЬЯНОВА

\section{В. Микаэль} КАССАЕ НЫГУСИЕ

Геннадий Яковлевич КОЗЛОВ

Игорь Георгиевич КОСИКОВ

Николай Павлович МЕДВЕДЕВ

Марина Николаевна МОСЕЙКИНА

Александр Данилович НАЗАРОВ

Дарья Вячеславовна ПЕРКОВА

Александр Васильевич ПОНЕДЕЛКОВ

Дмитрий Егорович СЛИЗОВСКИЙ

Шукран Саидовна СУЛЕЙМАНОВА

Жибек Сапарбековна СЫЗДЫкОВА
Председатель Совета, д.и.н., профессор, зав. кафедрой национальных и федеративных отношений РАНХ и ГС при Президенте РФ

\section{Редакционный Совет}

д.ф.н., постоянный представитель Российской Федерации при Организации Исламского сотрудничества

д.ю.н., профессор РАНХ и ГС при Президенте РФ

д.п.н., профессор Российской академии народного хозяйства и государственной службы при Президенте РФ

д.п.н., профессор Государственного университета управления

д.п.н., профессор Башкирского государственного университета

д.и.н., руководитель Центра исследования межнациональных отношений Института Социологии ФНИСЦ РАН

д.п.н., руководитель Центра по научному взаимодействию с общественными организациями, СМИ и органами государственной власти ИЭА РАН

д.п.н., профессор кафедры международного культурного сотрудничества МГИК

д.и.н., профессор кафедры теории и истории международных отношений Российского университета дружбы народов

д.и.н., профессор Рязанского государственного университета им. С.А. Есенина

д.и.н., главный научный сотрудник Института этнологии и антропологии РАН

д.п.н., профессор Российского университета дружбы народов

д.и.н. профессор, заведующая кафедрой истории России Российского университета дружбы народов

д.и.н., профессор, зам. руководителя кафедры по научной работе Московского авиационного института к.п.н., ответственный редактор

д.п.н., профессор, заведующий кафедрой политологии и этнополитики Южно-Российского института управления - филиал РАНХ и ГС при Президенте РФ

д.и.н., профессор кафедры истории России Российского университета дружбы народов

д.п.н., профессор Российской академии народного хозяйства и государственной службы при Президенте РФ

д.и.н., профессор, заведующая кафедрой стран Центральной Азии и Кавказа Института стран Азии и Африки Московского государственного университета имени М. В. Ломоносова, заместитель главного редактора журнала

Редакционная коллегия

Главный редактор - СУЛЕЙМАНОВА Ш.С., д.п.н., профессор РАНХиГС

Члены ред. коллегии:

Волох В.А. (зам. главного редактора),

Сыздыкова Ж.С. (зам. главного редактора),

Перкова Д.В. (ответственный редактор)

Болтенкова Л.Ф., Дробижева Л.А. Слизовский Д.Е.

\author{
УЧРЕЖДЕН \\ ООО «Издательство \\ «Наука сегодня»
}

\section{ЖУРНАЛ ВКЛЮЧЕН \\ В ПЕРЕЧЕНЬ ВАК РФ}

Журнал зарегистрирован Федеральной службой по надзору в сфере массовых коммуникаций,

связи и охраны культурного наследия

Регистрационный номер

ПИ № ФС77-47487

от 25 ноября 2011 г.

Журнал издается ежемесячно

Журнал включен в базу РИНЦ

(Российский индекс научного цитирования)

Включен в каталог

Ulrich's Periodicals Directory

Пятилетний импакт-фактор журнала: 1,006

Адрес редакции:

115598 , г. Москва, ул. Загорьевская, д. 10, корп. 4, цокольный этаж, помещение I, комната 7-1, офис 4

Тел.: (910) 463-53-42

www.etnopolitolog.ru

E-mail: etnopolitolog@yandex.ru

Мнение авторов может не совпадать с мнением редакции.

При перепечатке ссылка

на журнал обязательна.

Научные статьи, публикуемые в журнале подлежат обязательному рецензированию.

Ответственный редактор Перкова Д.В.

Компьютерная верстка Анциферова А.С.

Подписано в печать 25.04.2021.

Формат 60×84/8. Объем 24,3.

Печать офсетная.

Тираж - 1000 экз.

(1-й завод - 500 экз.

Заказ № 113

Отпечатано в типографии ООО «Белый ветер»

115054, г. Москва, ул. Щипок, 28

Тел.: (495) 651-84-56 
ISSN 2226-8596 (print)

12 выпусков в год и

2 выпуска в год переводной (англ.) версии

Языки: русский, английский

http://etnopolitolog

Входит в перечень рецензируемых научных изданий ВАК РФ

Включен в каталог периодических изданий Ульрих (Ulrich's Periodicals Directory: http://www.ulrichsweb.com) Материалы журнала размещаются на платформе РИНЦ Российской научной электронной библиотеки, Electronic Journals

Library Cyberleninka

Подписной индекс издания в каталоге агентства Роспечать 70114

\section{Цели и тематика}

Журнал ВОПРОСЫ НАЦИОНАЛЬНЫХ И ФЕДЕРАТИВНЫХ ОТНОШЕНИЙ - периодическое международное рецензируемое на ᄀучное издание в области политических исследований. Журнал является международным как по составу редакционного совета и редколлегии, так и по авторам и тематике публикаций.

Научный журнал издается с 2011 года в издательстве «Наука сегодня». С 2018 года издается переводная (англ.) версия журнала. С момента своего создания, журнал ориентировался на высокие научные и этические стандарта и сегодня является одним из ведущих политологических журналов России.

Цель журнала - способствовать научному обмену и сотрудничеству между российскими и зарубежными политологами

Журнал предназначен для публикации результатов фундаментальных и прикладных научных исследований. Тематическая направленность журнала отражается в следующих постоянных рубриках: «Отечественная история, этнология и этнография», «История международных отношений и мировой политики», «История и философия политики», «Политические институты, процессы и технологии», «Политическая культура, этнополитика и идеологии», «Политические проблемы международных отношений и глобализации».

Формат публикаций: научные статьи, обзорные научные материалы, материалы круглых столов, научные рецензии, научные сообщения, посвященные исследовательским проблемам в сфере политики и политологии.

В своей деятельности редакционный совет и редколлегия журнала руководствуется принципами, определяемыми ВАК России для научных журналов, в том числе: наличие института рецензирования для экспертной оценки качества научных статей; информационная открытость издания; наличие и соблюдение правил и этических стандартов представления рукописей авторами.

Целевой аудиторией журнала являются российские и зарубежные специалисты-политологи, а также аспиранты и магистры, обучающиеся по направлениям политология, государственное и муниципальное управление и международные отношения.

Журнал строго придерживается международных стандартов публикационной этики, обозначенных в документе СОРЕ (Committee on Publication Ethics) http://publicationethics.org

Полные сведения о журнале и его редакционной политике, требования о подготовке и публикации статей, архив (выпуски с 2011 года) и дополнительная информация размещена на сайте: http://etnopolitolog.ru

Электронный адрес: etnopolitolog@yandex.ru

ISSN 2226-8596 (print)

12 issues a year plus 2 issues a year of the translated (eng.) version Languages: Russian and English http://etnopolitolog

Included in the list of peer-reviewed scientific publications of the Higher Attestation Commission of the Russian Federation Included in the Ulrich's Periodicals Directory Materials of the journal are placed on the RSCI platform of the Russian scientific electronic library - Electronic Journals Library Cyberleninka Subscription index of the journal in the Rospechat Agency catalogue is: 70114

\section{Objectives and themes}

Academic journal "Issues of National and Federative Relations" is an international peer-reviewed scientific periodical in the field of political studies. The journal has an international character because of the composition of its Editorial Board, its editors, its contributing authors and topics of its publications.

The scientific journal is published since 2011 at the "Publishing House "Science Today". Translated (eng.) version of the journal is published since 2018. Since its inception, the journal was guided by high scientific and ethical standards and today it is one of the leading political science journals in Russia.

The purpose of the journal is to promote scientific exchange and cooperation between Russian and foreign political scientists.

The journal is intended for the publication of the results of fundamental and applied scientific research. Thematic focus of the journal is reflected in the following permanent headings: "Domestic history, ethnology and ethnography", "History of international relations and world politics", "History and philosophy of politics", "Political institutions, processes and technologies", "Political culture, ethnopolitics and ideologies", "Political problems of international relations and globalization."

Format of publications: scientific articles, reviews, scientific materials, materials of round tables, scientific reviews, scientific reports devoted to research problems in the field of politics and political science.

The Editorial Board and the editors of the journal in their activities are guided by the principles defined by VAK of Russia for scientific journals, including: presence of the institute of peer review for the expert quality assessment of scientific articles; information openness of the publications; availability and compliance with the rules and ethical standards for the submission of manuscripts by the authors.

The target audience of the journal is Russian and foreign specialists-political scientists, as well as graduate students and masters in the fields of political science, state and municipal management and international relations.

The journal strictly adheres to the international publishing standards and publication ethics identified in the COPE (COmmittee on Publication Ethics) document. http://publicationethics.org.

Full details of the journal and its editorial policy, requirements to the preparation and publication of articles, archive (issues since 2011) and additional information are available on the website: http://etnopolitolog.ru

E-mail address: etnopolitolog@yandex.ru 
ОТЕЧЕСТВЕННАЯ ИСТОРИЯ, ЭТНОЛОГИЯ И ЭТНОГРАФИЯ

Гасанов М.М. Дихотомия социально-поземельных

отношений в Дагестане во второй половине XIX века:

зависимые категории населения и крестьянство …………………….... 1006

Гусейнова $\boldsymbol{A} . \boldsymbol{A}$. Хазарский каганат

и народы Северного Кавказа

Пташко Т.Г., Перебейнос А.Е., Цилицкий В.С., Столбова Е.А.

Организация массового времяпрепровождения

Уральского населения в летний период

(вторая половина XIX - начало XX вв.)

Рогатко С.A. Развитие внутренней

и внешней мукомольной торговли в России

во второй половине XIX - нач. XX вв.

Ильясов Л.М. Религиозные традиции чеченцев

в древности и в средние века.....

Габбасова K.P. Театральные учреждения Башкирской автономной советской социалистической республики в годы Великой Отечественной войны (1941-1945 гг.): театральные кадры и кадровая политика государства 1049

Tитерина В.К. Крымский вопрос

в контексте греческого проекта 1060

Моргунов К.Г. Работа органов земского самоуправления по развитию народного просвещения в Таврической губернии в первое десятилетие земской деятельности (1866-1875 гг.)

Масленникова В.А. «Сгубить легко, да душе каково?»:

женщины-мужеубийцы середины XIX - начала XX вв.

(на примере Таврической губернии)

Скрипников П.Н. Научно-исследовательская работа

в медицинских вузах Западной Сибири

в кон. 1950-х - нач. 1990-х гг..

Зайнитдинов А.Ф. Социально-экономическое развитие

Северо-Восточной части Оренбургской губернии

в первой половине XIX века

\section{ИСТОРИЯ И ТЕОРИЯ ПОЛИТИКИ}

Болтенкова Л.Ф. Библия как источник права

(часть седьмая). 1099

Блинов В.B. Просвещенный традиционализм: рациональные

аргументы в пользу духовно-философского течения мысли

Цвижба Абзагу. Мистицизм и этнокультурные традиции

1000 ВОПРОСЫ НАЦИОНАЛЬНЫХ И ФЕДЕРАТИВНЫХ ОТНОШЕНИЙ • ВЫПУСК 4(73) • 2021 • Том 11 


\section{ПОЛИТИЧЕСКИЕ ИНСТИТУТЫ, ПРОЦЕССЫ И ТЕХНОЛОГИИ}

Кончугов А.В. Теоретические аспекты

современной модели военной безопасности России

Магадиев М.Ф. Криптографическая защита информации

в системе электронного правительства: современная российская

и международная практики .....

Крюкова E.B. Политическая журналистика

как фактор формирования общественного мнения.

До Tхань Ty. Особенности гражданских и политических практик

в интернет-пространстве вьетнамских пользователей:

результаты анализа массового опроса (2020 г.)

Ушаков И.Н. Политические инновации

в деятельности органов государственной власти

на основе интернет-коммуникаций

Нешков C.B. Массовые агитационно-пропагандистские

материалы политических протестных акций 2017 г. в России

ГОСУДАРСТВЕННОЕ УПРАВЛЕНИЕ И ОТРАСЛЕВЫЕ ПОЛИТИКИ

Родионова М.Е., Назарова Н.А., Гималиев В.Г., Емелин А.А.

Влияние пандемии COVID-19 на топливно-энергетический

комплекс России: краткий обзор

ТЕОРИЯ И ИСТОРИЯ МЕЖДУНАРОДНЫХ ОТНОШЕНИЙ

И ВНЕШНЕЙ ПОЛИТИКИ

Анненков В.И., Моисеев А.В., Шангараев Р.Н.

Энергетическая безопасность как фактор обеспечения

национальной и международной безопасности

Рубан Л.С., Бояркина А.В. Значение концепции Си Цзиньпина

«Сообщество единой судьбы человечества» в государственном

регулировании и международной политике Китая.

Курылёв К.П., Габриелян Г.Р., Фарактинова Е.Н.

Роль и место Центральной Азии в реализации Китаем

инициативы «Пояс и путь»

Чмырева В.А. Контуры сотрудничества ЕАЭС

с государствами и объединениями ЛАКБ:

новые внешнеполитические возможности России ....

Гусейнова Б.М. К вопросу о торгово-экономических

взаимоотношениях народов Дагестана и Азербайджана

в XVIII - первой половине XIX вв. 
Гехт А.Б., Шикунов А.Г., Соловьева В.А., Патрушева Д.А.

Подход А.Л. Вавина к концепции «мягкой силы»

Попов С.И., Шошич М. Системный кризис

миграционной политики стран Европейского Союза

в условиях третьей волны пандемии КОВИД-19

Жетпысбаев С.К. От межэтнических конфликтов к согласию ............ 1259

Шабловский В.C. Балканы во взглядах отечественных исследователей: от славянофилов до неоевразийцев

Чернышев P.С., Рашкован А.А. Эволюция и предпосылки

формирования проблемы кибербезопасности в международных

отношениях: первые хакерские атаки и крупные государственные

утечки данных в интернете

Семибратов E.B. Развитие системы европейской безопасности

в годы «холодной войны»: от формирования до распада.

Бай Сюетао. Состав китайцев на российском

Дальнем Востоке до Октябрьской революции

Ли Цзиньян. Перспективы всестороннего сотрудничества между Китаем и Африкой в рамках инициативы «Один пояс, один путь»

Темерев Д.В. Признание СССР со стороны США:

торгово-экономический аспект.

Степанов B.P. Татары Казахстана:

историко-культурный аспект (XIX - первая четверть XXI вв.)

Kрылова E.Г. Роль Российской Федерации

в решении конфликтов Закавказья

Баракат Кайс А.М., Шехада Мо Мин Т.Ф.,

Сейфи Мустафа С.M. Роль международных и региональных

организаций в урегулировании арабо-израильского конфликта

\section{СТУДЕНЧЕСКАЯ НАУКА}

Лапшин С.B. Хорватия: долгий путь к возрождению

Вэй Юйжуй. Влияние пандемии на развитие

отношений Китая и других государств мира.

КОНФЕРЕНЦИИ

Иианходжаева З.Р., Кобзева О.П., Раимов Р.И.

Алишер Навои. Сближая народы сквозь века 1356

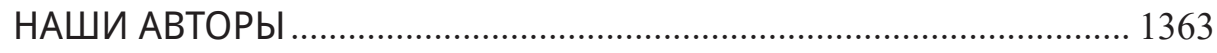

ТРЕБОВАНИЯ К ОФОРМЛЕНИЮ РУКОПИСЕЙ 1373 
докторант Центра изучения русского языка, литературы и культуры Хэйлунизянского университета, Сюэфу, уезд Нанганг, Харбин, провинция Хэйлунизян, Китай

\section{СОСТАВ КИТАЙЦЕВ НА РОССИЙСКОМ ДАЛЬНЕМ ВОСТОКЕ ДО ОКТЯБРЬСКОЙ РЕВОЛЮЦИИ}

После подписания российско-китайского договора в 1860 г. и Россия оккупировала Дальний Восток, и китайцы решили уехать в Россию, чтобы заработать на жизнь из-за различных факторов внутри страны и за рубежом. Китайцы занимались различными видами экономической деятельности на Дальнем Востоке, такими как коммерческая торговля, экспорт рабочей силь и сельскохозяйственное производство. В определенной степени китайцы играли важную роль в решении проблем спроса на сырьевые товаpы, нехватки рабочей силь и продовольственного обеспечения в период развития и строительства российского Дальнего Востока. Собирая и сортируя отечественные и зарубежные литературы и документы, автор попытается исследовать причины выезда китайщев в Россию, чтобы заработать на жизнь, состав персонала, и подчеркивает глубокое влияние китайчев на повседневную жизнь и развитие и строительство Дальнего Востока.

Ключевые слова: Октябрьская револючия, Россия, Дальний Восток, киmaйuฺbl.

Исторические корни китайцев на русском Дальнем Востоке. До подписания китайско-российского «Пекинского договора» в 1860 году китайцы уже жили вдоль реки Хэйлунизян, вдоль Уссури и в других районах Дальнего Востока. История китайской деятельности в регионе восходит к началу VIII века н.э., когда династия Тан учредила в регионе столииу. Последующие династии осуществляли юрисдикиию над регионом Хэйлунизян. К династии Цин различные этнические группы, проживающие к северу от реки Хэйлунизян и к востоку от Уссури, были переданы под юрисдикиию генералу Хэйлунизян и генералу Цзилинь, соответственно [6. С. 64].

Подписание китайско-российского договора и динамика внутреннего положения Китая. После подписания «Пекинского договора» в 1»860 году Россия оккупировала более миллиона квадратных километров земли к северу от реки Хэйлунцзян и к востоку от Уссури в Китае, и благодаря усилиям 
правительства Цин некоторые положения договора защищали и гарантировали интересы местных китайских жителей, проживающих на Дальнем Востоке. Пекинский договор включал следующее: востоку от Уссури китайцам будет позволено ловить рыбу и охотиться, как обычно, а Россия не должна занимать никакого места, где живут китайцы или где китайцы занимают рыболовные и охотничьи угодья... Установленные пограничные места должны позволять людям, принадлежащим к обеим странам, свободно торговать без уплаты налогов, а чиновники на каждой границе должны заботиться о торговле купцами.... В 1879 году было подписано «Положение о торговле землей, согласно которому в пределах 100 миль от границы между двумя странами гражданам Китая и России разрешается торговать по своему усмотрению без уплаты налогов». Пересмотренный в 1881 году Устав земельной торговли включал: В пределах ста миль от границы между двумя странами народу Китая и России разрешается торговать так, как он хочет, без уплаты налогов. Содержание вышеупомянутых договоров и торговых соглашений в некоторой степени противоречило политике династии Цин, направленной на блокирование северо-востока, что давало возможность китайцам в материковом Китае путешествовать дальше в Россию, а численность китайцев на Дальнем Востоке постепенно увеличивалась.

В 1860 году правительство Цин отменило запрет на «землю процветания дракона» на северо-востоке и «решило открыть ее частично». Под влиянием снятия запрета многие жители Гуаньчжоу отправились на северо-восток, чтобы заработать на жизнь, а некоторые иммигранты, прибыв на северовосток, решили продолжить свой путь на север, на Дальний Восток России, чтобы заняться трудовой и другой деятельностью. В то же время правительство Цин продолжало эмигрировать из других районов, чтобы усилить пограничные силы с целью усиления пограничной обороны. Со второй половины XIX века до начала XX века резко возросло население северо-восточной области и обострилось противоречие между людьми и землей; многие крестьяне обанкротились, а некоторые из тех, кто потерял свои земли, также уехали на Дальний Восток, чтобы заработать на жизнь.

В 1865 году правительство Цин официально признало легализацию китайских рабочих, выезжающих за границу: Китайское правительство признало, что китайские рабочие могут свободно выезжать за границу и не возражает..., что обеспечивало правовую защиту выезжающих в Россию китайских рабочих. В последние годы число китайцев, прибывших в Восточную Приморскую провинцию... составляло около 16500 в 1895 году; в 1896 году - более 35 000; в 1897 году оно увеличилось еще больше до 70 000. Причина их прибытия заключается в том, что строительство баз во Владивостоке и в других местах нуждается в людях.

В конце XIX века в густонаселенные районы, такие как Шаньдун и Хэбэй, из-за различных причин, таких как стихийные бедствия, череда войн 
и империалистических посягательств, привели к серьезной аннексии земель, и площадь, обрабатываемая людьми, продолжала сокращаться, а многие крестьяне были сведены к арендаторам и находились в трудном положении. Стихийные бедствия в провинциях Шаньдун, Чжили и Шаньси были настолько вредны, что каждый год они поражали до пятидесяти или шестидесяти штатов и округов, и до ста. В 1894 году наводнение пострадали сто десять штатов и уездов, и только в Таншане было более ста тысяч голодающих людей, к которым некуда было обратиться за помощью. В то же время, с 1894 по 1905 год на севере Китая происходило много крупномасштабных войн, и многие люди страдали невинно и были вынуждены покинуть свою родину. Некоторые из перемещенных лиц начали уходить на север, чтобы прорваться через Гуаньдун, и даже переправились через реки Хэйлун и Уссури на Дальний Восток, чтобы заняться сельским хозяйством или трудовой деятельностью.

Большое количество китайцев мигрировало на север, на северо-восток Китая и даже на российский Дальний Восток, как возможность для собственного выживания и развития, и по этим причинам число китайцев на Дальнем Востоке увеличилось.

Привлечение российской иммиграционной политики. Изменение численности китайцев на Дальнем Востоке было тесно связано с миграционной политикой России. В 1860 году, после того как Россия заняла более миллиона квадратных километров земли к северу от реки Хэйлунцзян и к востоку от Уссури в Китае, она была вынуждена полагаться на китайские поставки для поддержания своей повседневной жизни в течение довольно долгого времени из-за небольшого количества русских в этом регионе. 27 апреля 1861 года российское правительство издало постановление об эмиграции русских и иностранцев в Амурскую и Приморскую губернии с целью укрепления своего господства над Дальним Востоком: Всем русским и иностранцам, добровольно поселившимся в Амурской и Приморской губерниях, разрешается выделять свободные земли.... Под влиянием этой политики число китайцев на Дальнем Востоке росло быстрее. После 1870 года, в районе вдоль реки Уссури, где жили китайцы, ежегодно въезжало около 500 китайцев. В 1873 году число китайцев во Владивостоке выросло до 18 000, в Шуанчэнчжоу - более 8 000, в Бури - около 4 000, в Хайланпо - более 2 000. В 1885 году во Владивостоке 28000 китайцев. Бизнес в Гуандуне огромен, а люди больше в Шаньдуне.

В конце XIX века Россия начала строить военные базы и порты, а также другие проекты и развивать минерально-сырьевые ресурсы на Дальнем Востоке, что требовало большого количества рабочей силы. Однако наем российских рабочих из европейской части России был дорогостоящим и трудоемким, и многие российские рабочие приехали на Дальний Восток и уехали в связи с тяжелыми условиями и другими причинами, многие рос- 
сийские рабочие уехали после приезда на Дальний Восток из-за суровых условий и других причин, которые замедлили ход строительства. Российское правительство и предприниматели начали нанимать на строительство китайских рабочих. В 1891 году начались работы по строительству Великой Сибирской железной дороги, и российское правительство ежегодно набирало десятки тысяч китайских рабочих из провинции Шаньдун Китая для строительства железной дороги. Только на Уссурийском участке железной дороги в 1891 году насчитывалось около 3000 китайских рабочих, а к 1900 году число китайских рабочих достигло 12200 человек, что составляло около 84,1\% от общего числа рабочих. В этот период китайцы были главной рабочей силой в строительстве Дальнего Востока в России и приносили большие жертвы во имя развития Дальнего Востока.

Китайские общества взаимопомощи способствовали росту числа китайцев на Дальнем Востоке. Китайцы на Дальнем Востоке спонтанно сформировали различные общества взаимопомощи в соответствии со своими кровными и географическими связями. Китайские купцы на Дальнем Востоке сформировали несколько крупных купеческих банд по своему происхождению, в том числе Северную банду (провинции Хэбэй и Восток), Восточную банду (Шаньдун), Южную банду (район Цзяньнань) и Кантонскую банду (Гуандун). Например, в 1895 году почти все сотрудники в двух китайских лавках в Благовещенске были из одной провинции или города [1].

Члены Китайской ассоциации взаимопомощи помогали друг другу и соблюдают установленные ими уставы. В 1860-х годах китайцы, опираясь на кровные связи, сформировали Гюйюбикай (Гун-и-хуэй), который к началу XX века вырос до более чем 300 членов. В конституции взаимовыгодного общества прямо говорится, что воровство, ссоры, поиск вины запрещены; азартные игры запрещены в течение 11 месяцев в году; помощь оказывается братьям, находящимся в бедственном положении и больным; члены общества защищены от воров и грабителей.... [2. С. 144]. Развитие Содружества постепенно монополизировало закупочные цены на женьшень, шкуры и рога в Уссурийском регионе, и Содружество получило значительные выгоды в этом регионе.

Китайское общество взаимопомощи использовало кровные и географические связи как связующее звено для объединения своих членов и оказания помощи китайцам, прибывающим на Дальний Восток. С помощью Дальневосточной ассоциации взаимопомощи китайцы, впервые приехавшие в регион на работу, смогли за короткое время решить свои финансовые и жизненные проблемы. Президент Хабаровской китайской ассоциации Цзи Фэнтай не раз помогал впервые приехавшим в Россию из уезда Хуан, провинция Шаньдун, и предоставлял им финансовые кредиты и услуги по размещению, чтобы они могли без проблем работать на Дальнем Востоке. 
Тот факт, что китайцы живут вместе, помогают друг другу, соблюдают правила и положения обществ взаимопомощи, работают для достижения общей цели, в значительной степени укрепил сплоченность китайцев и заставил больше отечественных китайцев работать в России.

\section{Структурный состав китайцев на российском Дальнем Востоке.}

Коренные и сезонные китайцы.

Когда русские впервые появились в районе Хэйлунцзян и Уссури, этнические меньшинства, такие как ханьские китайцы, Хечер и Орокен, были операторами и застройщиками этой земли, в дополнение к некоторым сезонным китайцам, приезжающим в этот район для работы.

Коренные жители вдоль рек Хэйлунцзян и Уссури. Этнические меньшинства Даур, Орокен и Хежен уже давно живут в северной приграничной области Китая и занимаются рыболовством и охотой вдоль рек Уссури и Хэйлун и даже в районе Курильских островов (Сахалин). В 1680-х годах дауры и эвенки уже жили за Зейским районом. В конце XVII века за Зейским районом появились маньчжурские знамена и другие китайцы, прибывшие сюда позже и постепенно сформировавшие свое поселение, Маньчжурский тун (Маньчжурский клин), на левом берегу реки Хэйлунцзян (1) [3].

Японский ученый Мамия Ринзоу в своей «Хронике Восточной Тартарии» описывает повседневную деятельность этнических меньшинств, таких как Хежен, Феяка и Орокен в низовьях реки Хэйлунцзян, на Камчатке и на Курильских островах в начале XIX века, а также административное образование в регионе династии Цин и управление ею меньшинствами.

Первоначальными обитателями района вдоль рек Хэйлунцзян и Уссури до 1860 г. были, в основном, Восьмизнаменники, размещенные в Айгуне, а также Орокен, Даур, Эвенк (Соломоны), Хетце (Горды), Феякас (Кирикияс), и коренные жители Курильских островов, а также некоторые ханьские китайцы (в России их называют варварами). Большинство ханьцев в регионе занимаются сельским хозяйством, коммерческой торговлей и собирательством, в то время как орокини, хэчжэ и другие группы меньшинств в основном занимаются рыболовством и охотой, а небольшое число орокини и герже ведут оседлый образ жизни под влиянием ханьцев и научились хозяйству.

Из-за длительной истории трудно найти подробную информацию о населении коренных жителей вдоль рек Хэйлунцзян и Уссури и других районов Дальнего Востока до 1860 года. Записано, что до 1860 года от реки Гурбизи до Хортокоу, на левом берегу недалеко от города Хэйлунцзян, справа от флага находились более тридцати кантонов, а в общей сложности более пятидесяти кантонов Маньчжоу и Китая, с населением более десяти тысяч человек [2. С. 6-7]. Надалов отмечает, что до «Пекинского договора» 1860 года, 872 ханьцев поселились в Уссурийском районе [12. С. 91]. Кроме того, до 1860 г. китайцы в Южном Уссури собирались в основном в долинах 
рек Суйфен, Лефу, Даггерби, Ула и Сухан, и могли быть разделены по своим ремеслам на три категории: охота, сельскохозяйственные работы и другие [10. С. 63]. По данным опроса Б. Гравия, на момент подписания «Пекинского договора» в 1860 г., когда территория вдоль реки Хэйлунцзян была официально присоединена к России, в Амурской области проживало около 15000 китайцев, разбросанных по 44 деревням между рекой Хыя и Хорморетуном, из которых 5400 были ханьцами (3240 мужчин и 2160 женщин), а остальные - даурами и маньчжурами. Около 900 китайцев поселились в районе вдоль реки Уссури [12. С. 89-94].

Кроме того, по данным опроса населения, проведенного российскими властями в 1870 году, в стране насчитывалось 16 маньчжурских деревень и 14 китайских и даурских селений с населением 3286, 5400 и 1960 человек соответственно. В 1883 году российское правительство вновь провело опрос населения 64 деревень, и число китайцев увеличилось до 13923 человек, в том числе 1700 дауров, 4400 маньчжуров и 7900 ханьцев [5. С. 2].

Что касается количества китайцев в Уссурийском районе, то в 1879 году Надалов отметил, что в регионе насчитывалось 1171 китайский дом и 6856 китайцев [12. С. 91]. Кроме того, к 1880 г. в приграничной зоне Северного Уссури на реках Хор, Бикин, Иман и Ваку в верхней части района насчитывалось 242 гетчен и 855-1148 орокен [9. С. 23-25].

Помимо упомянутых выше коренных жителей, на Дальнем Востоке было много китайских иммигрантов, занятых сезонной деятельностью. Китайские иммигранты, занятые сезонной деятельностью, были в основном сборщиками женьшеня, золотоносцами, рыбаками и охотниками, сборщиками горной продукции и кратковременными работниками.

Поскольку Дальний Восток был богат норкой, пантами, женьшенем, грибами и богатыми морскими продуктами, каждое лето большое количество китайцев ныряло в этот регион, чтобы поохотиться за ресурсами. До того, как Уссурийский край был передан России, правительство Цин ежегодно посылало людей в этот регион для сбора женьшеня, охоты на горностай и т.д. Их численность составляла около 200 человек. До 1860 года сотни китайцев ежегодно занимались поиском золота на острове Аскольд в Приморской губернии [10. С. 63]. После 1860 года, когда этот район был передан под юрисдикцию России, многие китайцы все еще ежегодно приезжали в этот регион. В конце XIX века около 30000 сезонных китайских рабочих присутствовали в Хабаровске, Владивостоке и нескольких городах ЮжноУссурийского края. Кроме того, около 2 000-3 000 китайцев ежегодно занимались сезонными раскопками женьшеня и охотой к востоку от Уссури.

Ранние китайские купцы в России. Деятельность китайских купцов на Дальнем Востоке восходит к началу XVIII в. После подписания китайскороссийского договора Чакотау в 1727 г. большое число китайских купцов прибыло на российский Дальний Восток морским и сухопутным транспор- 
том, а затем перешло к ведению дел в центральных и западных областях России. В первые годы Дальнего Востока, в связи с малочисленностью земель, китайские купцы были в основном мелкими торговцами [7. С. 22-23]. Они переходили с улицы на улицу, бродили по улицам, используя различные методы торговли, такие как кредит и консигнация. Они продавали в кредит и от имени других, и их бизнес был очень процветающим, и они распространились по всем городам и даже по незаселенным девственным лесам, обеспечивая жителей Дальнего Востока продуктами, в которых они нуждались для своей жизни. Согласно Айгуньским уездным записям, когда русские строили Благовещенск на противоположном берегу Хэйхэтун, «они приглашали китайских купцов торговать друг с другом». С тех пор магазины в Айгуне открыли филиалы в Хайхетуне, и купцы каждый день переправлялись через реку, чтобы торговать, что было очень процветающим занятием. В районе 64 кантонов на Цзяндун, хотя в каждом кантоне мало маленьких магазинов, в кантоне Патч насчитывается более 30 винных магазинов [13. С. 5].

После подписания «Пекинского договора», по данным опроса Надарова о китайской купеческой общине на Дальнем Востоке: в 1879 году из почти 7000 китайцев в Уссурийском районе насчитывался около 141 купца с объемом торговли 308210000 рублей. Из них 100 китайских купцов находились только во Владивостокской области, а объем торговли составил 275860000 рублей [9. С. 104].

Некоторые цинские чиновники также записали информацию о положении китайской купеческой общины в России во второй половине XIX века. В 1881 году Ли Цзиньун, чиновник из Цин, написал в рапорте правительству Цин: «Во Владивостоке проживает более 7000 китайцев и сотни десятков торговцев, в основном из Ци и Лу, за ними следуют Цзянси, Чжэцзян, Фуцзянь и Каньтон» [14. С. 5]. В 1885 г. Цао Цзиньцзе, чиновник из Цзилиня, также зафиксировал положение китайских купцов, путешествовавших в Россию на раннем Дальнем Востоке во время осмотра российско-китайской границы: «При проверке Владивостока... насчитывается до 28 тыс. китайцев (общее количество русских чиновников при проверке в девятом году Гуансюй, и около 20 тыс. при проверке в одиннадцатом году Гуансюй). Бизнес в Гуандуне огромен, а люди больше в Шаньдуне, есть три китайские улицы, и русские установили там Министр Губилату для надзора за делами. Только в пяти местах - Бури, Шуанчжэнзи, Владивостоке, Хунтуане и Янчухэ - были китайские магазины более 300 различных размеров, каждый со своим рынком и бизнесом» [11. С. 125].

Появление китайских рабочих в России. В 1860 году был отменен декрет, запрещающий гражданам страны работать за границей, и китайцам было разрешено выезжать на работу за границу. Это способствовало масштабному привлечению китайских рабочих для развития Российского Дальнего Востока. Китайские рабочие на Дальнем Востоке были широко 
распространены, от крупных городов до отдаленных Курильских островов и даже до Командорских островов в северной части Тихого океана.

Формальный и организованный экспорт китайских рабочих на российский Дальний Восток начался в 1870-х годах. До 1870-х годов большое количество китайцев уезжало на Дальний Восток, чтобы зарабатывать на жизнь, но делали это спонтанно, не в истинном смысле экспорта рабочей силы. В середине 1870-х годов российские власти наняли 150 китайских рабочих из провинций Чжили и Шаньдун и начали использовать китайскую рабочую силу для развития и строительства Дальнего Востока, что дало хорошие результаты [5. С. 3]. В 1870 году в Уссурийском районе уже постоянно проживало 1797 китайских рабочих, что в два раза больше, чем в 1860 году. В 1880 году число китайских рабочих увеличилось до 6628 человек. В 1881 году численность проживающих в Амурской и Приморской губерниях китайцев достигла 15228 человек. К началу XX века число китайских рабочих на Дальнем Востоке росло еще быстрее.

Китайские рабочие на Дальнем Востоке были в основном молодыми людьми. Сохраняя чрезвычайно низкие экономические расходы, они накапливали 150-300 рублей в период с марта по декабрь каждого года, и затем привозили обратно в Китай [8. С. 7]. Китайские рабочие в России были трудолюбивыми, и способными, требовали низкой заработной платы. Так, в середине 80-х годов китайским рабочим на Владивостокских доках платили не более 85 копеек в день на человека, а российским рабочим по 1-1,5 рубля в день, что вызвало большой интерес со стороны российского правительства и частных предпринимателей [3]. М.В. Нестеров пишет: Потребности китайских рабочих были невысоки, их пища была простой, в основном рис, крупы и соевое масло, их одежда была только рубашками и брюками, иногда вообще без рубашек, и они носили одну и ту же пару обуви на ногах все время, пока не износились [4. С. 7-8]. Журналист А. Вережников также сообщил: «Бригадные китайские рабочие, как правило, не предъявляют никаких требований к своим работодателям, кроме дневной заработной платы. Они живут в собственных палатках или хижинах, и у них гораздо меньше еды, чем у русских - менее полутора русских фунтов в день».

Приспосабливаемость и способность к обучению китайских рабочих в России были настолько сильны, что они могли не только выполнять свою работу, но и быстро осваивать другие ремесла, такие как плотницкие работы, строительство печей и покраска.

Заключение. В заключение следует отметить, что китайцы на российском Дальнем Востоке жили до 1860 года и были вовлечены во все сферы жизни Дальнего Востока, от трудолюбивых китайских рабочих до богатых китайских купцов. С 1860 года до Октябрьской революции китайцы преодолевали шторм, но все равно продолжали упорно трудиться на Дальнем Востоке. Китайцы на российском Дальнем Востоке всегда были силой, которую нельзя игнорировать в истории Дальнего Востока и в изучении китайцев за рубежом. 


\section{ПРИМЕЧАНИЯ:}

(1) То есть, китайский Манхус.

\section{БИБЛИОГРАФИЧЕСКИЙ СПИСОК:}

1. Государственный архив Амурской области. И-8. Оп. 1. Д. 33.

2. Граве B.B. Китайцы в прибрежном районе Амура / перевод Се Чунхе и др. Харбин: Хэйлунцзянское Образовательное издательство, 2014.

3. Залесская O.B. Хозяйственная и криминальная деятельность китайского населения на Дальнем Востоке России В конце XIX - начале XX вв. // http://ru.apircenter.org/archives/3704.14.05.2015.

4. Зиновьев В.П. Китайские и корейские рабочие на горных промыслах Сибири и Дальнего Востока в конце XIX - начале XX в. // Вопросы экономической истории России. Томск: ТГУ, 1996.

5. Инь Цзяньпин. Иностранный труд в раннем развитии Дальнего Востока // Сибирь. 1997. № 4.

6. Комитет по составлению местной истории провинции Хэйлунцзян. История провинции Хэйлунцзян - иностранные дела. Народное издательство провинции Хэйлунцзян, 2002 г.

7. Ларин А.Г. Китайцы в России вчера и сегодня // Муравей. 2003 г.

8. Ларин А.Г. Китайская иммиграция в России (1850-1920-е гг.) / Академия Синицы. Институт современной истории // Сборник статей. 1996 г.

9. Надаров И.П. Северный Уссурийский край. Шанхайское народное издательство, 1975 г.

10. Унтерберг П.Ф. Приморский край (1856-1898) // Коммерческая пресса. 1980 г.

11. Цуу Пэйюань, Чжао Минции. Собрание сочинений Цао Цинцзе // Китайское книжное бюро. 1985 г.

12. Чжсан Зонхай. Китайско-российские отношения на Дальнем Востоке на рубеже веков. Народное издательство Хэйлунцзян, 2000.

13. Чжсан Зонхай. Становление и развитие китайских купцов на российском Дальнем Востоке с конца XIX века до начала XX века // Журнал русских исследований. 2015. № 2.

14. Чжан Зонхай. Формирование и развитие китайских торговцев на российском Дальнем Востоке с конца XIX начала XX века // Русский журнал. 2015. № 2 . 
BAI XUETAO

Ph.D., Center for Russian Language Literature and Culture Studies of Heilongjiang University Xuefu Road, Nangang District, Harbin, Heilongjiang Province

\title{
THE COMPOSITION OF OVERSEAS CHINESE IN THE RUSSIAN FAR EAST BEFORE THE OCTOBER REVOLUTION
}

\begin{abstract}
After the signing of the "Beijing Treaty" in 1860, Russia occupied the Far East, and the Chinese chose to go to Russia to make a living due to various factors at home and abroad. The Chinese are engaged in various economic activities such as commercial trade, labor export and agricultural planting in the Far East. To a certain extent, the Overseas Chinese have played an important role in solving the problems of commodity demand, labor shortage and food supply during the development and construction of the Russian Far East. Through the collection and sorting of domestic and foreign documents, this article attempts to explore the reasons, composition of the Overseas Chinese to make a living in Russia, highlighting the profound influence of the Overseas Chinese on the daily life, development and construction of the Far East.
\end{abstract}

Key words: October Revolution; Russia; Far East; Overseas Chinese; activities. 